\title{
A Study on the Research Model for Healthy Urban and Architectural Environment
}

\author{
건강한 건축·도시환경을 위한 연구모형 구축에 관한 연구
}

Choi, Kwangseok* 최광석

\begin{abstract}
Purpose: Health is one of the most important interests in current and future human society. Various efforts, which to maintain and promote their good health conditions, continue to be tried in future urban and architectural environment. The purpose of this study is to establish an integrated framework of research approaches for healthy urban and architectural environment that continuously promotes health according to people's entire life course. Methods: This was done by literature reviews, which is related to interdisciplinary researches for the determinants of health and healthy environment. Results: As a result of this study, an integrated research model, as a methodology, was proposed. This explains the concept of integrated research approaches for urban and architectural environment in the respect of people's health. Integrated health concept includes not only the area of health care environment to have recovery and treatment but also the daily living environment for people who have potential of being ill, and finally the city environment for entire people as health supporting elements including safety and primary prevention. Implications: Under the basis of this model, according to the life course, various researches on sustainable healthy urban and architectural environment should be followed from now on. The model should also be continuously complemented and developed into a standard of healthy environment.
\end{abstract}

Keywords Health, Architectural Planning for Health, Healthy City Environment, Ecological Environment, Evidence-Based Design, Health Care Environment

주 제 어 건강, 건강건축계획, 건강도시환경, 친환경, 근거기반디자인, 보건의료환경

\section{Introduction}

\subsection{Background and Objective}

우리 사회가 선진화되고 고령화 사회로 진입하면서 건강 과 삶의 질 그리고 정주환경에 대한 관심이 높아져 건강과 환경이 서로 밀접한 관계를 갖는 하나의 개념으로 통합되 고 있다. 건강이라는 문제는 이제 비위생적인 환경이나 질 병 같은 관점이 아니라 정신건강이나 환경이 인간에게 미 치는 생리적, 심리적 영향 등으로 확대되고 있으며, 학문분 야도 의학, 간호학, 건축학, 도시학, 조경학, 주거학, 심리학 등 다학제적인 영역으로 넓혀지고 있다. 건강은 현재와 미 래의 사회에서 가장 중요한 관심사의 하나로서 앞으로 우 리가 살아가는 건축과 도시환경에서 건강을 유지하고 증진 시킬 수 있는 노력과 방법이 지속적으로 모색될 것이라 생

* Editor, Ph.D., Korea Institute of Hospital Architecture (Primary author, daumchois@hanmail.net)
각한다.

최근에는 양극화와 지역적 격차가 심화되고 복지문제와 함께 건강의 불평등이 사회적인 문제가 되고 있다. 이것은 모든 사람의 건강을 요구하는 $\mathrm{WHO}$ 의 정신에 위배될 뿐만 아니라 사회정의 차원에서도 건강자원에 대한 국가적인 정 비가 필요한 실정이다. 건강이란 어떤 특정시점의 위험보 다 생애 전반에 걸쳐 축적되므로 의료시설과 같은 특정 대 상과 환경이 아니라 사람의 전 생애주기를 대상으로 지속 적으로 건강을 증진시키는 환경을 만드는 노력이 필요하다. 우리나라는 앞으로 의료 및 복지비용이 증가함으로서 사회 부담이 커질 것으로 예상되는데, 질병에 걸리기 전에 건강 을 유지하도록 지속가능한 건강 환경을 만들어가는 것이 비용 효율적이며, 개개의 환경레벨에서 자발적인 비용의 분 담을 통해 미래의 사회 및 공적 부담완화에도 일조할 수 있 을 것이라 생각한다.

본 연구는 앞으로의 건축과 도시계획의 상위개념을 건강 
과 환경과의 만남이라 보고, 건강의 결정요인과 환경과의 복합적인 관계에 대한 다학제적인 이론을 고찰하고, 건축, 도시 분야의 분산된 건강관련 연구의 동향을 분석함으로서, 앞으로 건강한 건축과 도시환경 구축을 위한 연구방법론으 로서 통합적인 연구모형을 제시하였다.

\section{Health and Environment}

\subsection{Changes of Health Concepts}

세계보건기구(WHO)의 오타와헌장(1986)에 따르면 "건강은 단순히 질병이나 허약함이 없는 상태뿐만이 아 니라 물리적, 정신적, 사회적으로 안녕한 상태”를 말한다 (L.J. Duhl \& A.K. Sanchez, 1999: 21). 이것은 건강이 전통적인 보건의료와 공중보건의 영역인 생의학적 모델 (Biostatistical Theory of Health)을 넘어 생물학의 외적 요인까지 보다 더 넓은 영역에서 건강을 결정하는 웰니스 (Wellness Movement)와 홀리스틱 모델(Holistic Theory of Health)로 확장된 것을 의미한다.

19세기 후반 과학의료의 도입 이래 보건의료는 모든 질 병과 의료의 불평등을 제거할 것처럼 비약적인 발전을 이 루었고, 사망률의 감소와 평균수명의 증가 그리고 전염병과 많은 급성기 질환의 위험성을 줄이는데 크게 기여하였지만, 현대사회는 여전히 질병의 고통으로 신음하고 있고, 건강의 불평등도 개선되지 않았다는 비판을 받고 있다. 또한 사회 의 발전과 고령화를 통해 다양한 원인이 복합되어 발생하 는 만성질환이 급성질환의 자리를 대체해 감으로서 그 배 경이 되는 개인의 일상적인 삶의 방식과 사회적 맥락의 중 요성이 부각되기에 이르렀다. 이러한 배경으로부터 건강의 개념은 개인의 질병이라는 생의학적 시각으로부터 사회적 요소와 같은 복합적인 영역까지를 고려해야 한다는 것으로 인식이 변화되었다.

우리나라는 이러한 변화가 외국에 비해 더 심화되는 징 후가 나타나고 있다. "최근 전체 사망의 약 $60 \%$ 는 암, 뇌졸 중, 심장질환, 당뇨와 같은 만성질환에 의한 것이며, 인구의 급속한 고령화로 이러한 질병구조의 변화는 더욱 가속화되 고 있다" (김동현, 2011; 4). 또한 소득의 양극화, 수도권 편 중현상 등 사회적, 지역적인 불평등이 심화되고 있는 상황 이며, 이러한 사회경제적인 격차가 개인 및 계층(고소득자: 저소득자, 노동계층:비노동계층, 정규직:비정규직, 정상인: 사회적 약자, 남:녀:아동:노인 등), 지역(수도권:지방, 부유 촌:낙후지역, 대기업:중소기업, 등). 더 나아가 한국이라는 국가 차원의 건강불평등을 만들고 있다.

2010 년 우리나라의 연령표준화 자살률은 인구 10 만 명당33.5명으로 $\mathrm{OECD}$ 국가 평균 12.8 명에 비해 크게 높았으며, 본인의 건강상태가 양호하다고 생각하는 비율 은 $37.6 \%$ 로 $\mathrm{OECD}$ 평균인 $69.8 \%$ 에 크게 못 미쳤다 (Figure 1).

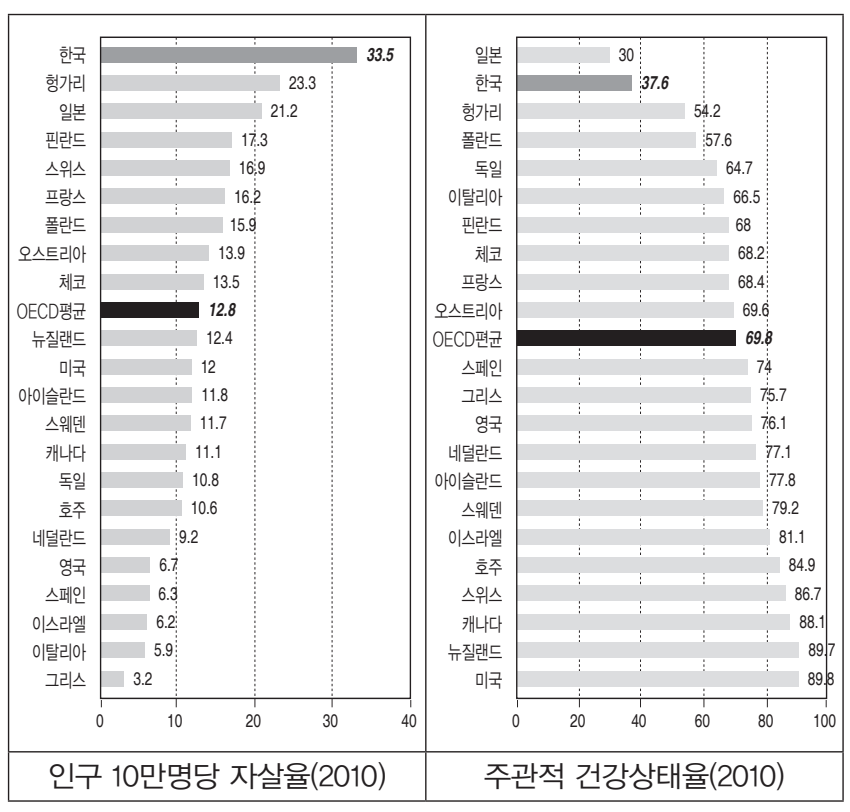

[Figure 1] Health Inequalities in OECD Nations (보건복지부, 2012; $36 \sim 43)$

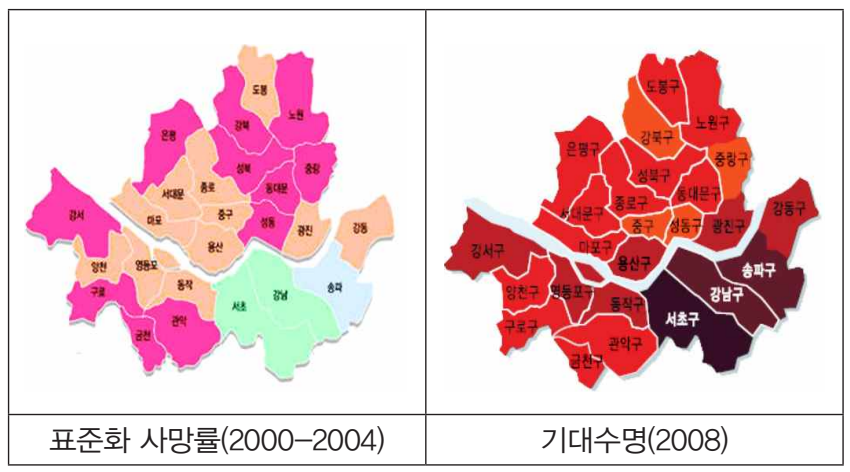

[Figure 2] Health Inequalities by borough in Seoul (진한 색일수록 사망률과 기대수명이 높음)

2000년에서 2004년 동안의 성연령 표준화 사망률 조사 에 따르면, "강북구에 사는 사람이 질병, 사고 등으로 숨질 가능성은 서초구, 강남구에 사는 사람보다 $30 \%$ 가량 높은 것으로 나타났다" (Figure 2, 한겨레, 2006, quoted in 강 영호, 2012; 41). 또한 “2005년에서 2010년 동안 서울시 에서 사망률이 가장 낮은 자치구는 서초구, 강남구와 송파 구 순으로, 가장 낮은 서초구의 사망률이 인구 10 만 명당 연평균 335명이었던 반면, 가장 높은 자치구는 연평균 469 명이었다" (서울시 복지건강실 보건정책과, $2012 ; 5$ ). 한 편, 서울대 보건대학원 조영태 교수 연구팀이 2008년 연령 별 사망률을 토대로 서울 각 구별 기대수명을 산출한 결과, "서초구 남성의 기대수명이 83.1세로 가장 길었고, 송파구 81.1세, 강남구 81.0세 순이었으며, 나머지 22개 구는 80세 를 밑돌았다. 남성 기대수명이 가장 낮은 구는 강북구(77.9 세)로 서초구와는 5.2년의 차이가 있었다. 이 같은 현상은 두 지역의 건강검진율 음주율 흡연율 비만율 소득 교육수 
준 등 경제적, 사회적 환경 격차에 따른 것으로 분석된다" (Figure 2, 김원철, 20110224).

이와 같이 지역적 불평등 여건을 포함하여 교육수준, 직 업, 소득 같은 사회경제적 위치는 건강과 질병, 건강관련 행 태와 밀접한 관계가 있다. 즉, "사회 경제적 지위가 높을수 록 건강수준도 높다는 연구 결과는 가장 견고한 역학 연구 결과중의 하나이다" (최용준, 2007; 475).

로이드와 뉴웰은 소득수준과 같은 사회경제적인 불평등 이 어떻게 개인의 생활방식과 건강에 영향을 미치는지를 설명하였다(Figure 3). 예를 들면 고용불안은 개인의 비고 용, 비숙련 노동 등으로 신체적 위험과 낮은 소득을 얻게 하 며, 그 결과, 열악한 주거수준과 빈곤 등의 빈곤한 생활양식 을 갖게 한다. 이 빈곤한 생활은 태어나는 아기에게 빈약한 주거환경과 건강을 갖도록 하며, 학령기가 되어도 불량행동 문제와 낮은 학업성적을 보이게 되며, 건강관리도 빈약하여 학교 졸업후, 취업에 나쁜 영향을 주게 된다. 이와 같은 불 평등은 어떤 중재가 없다면 계속하여 악순환을 하게 된다.

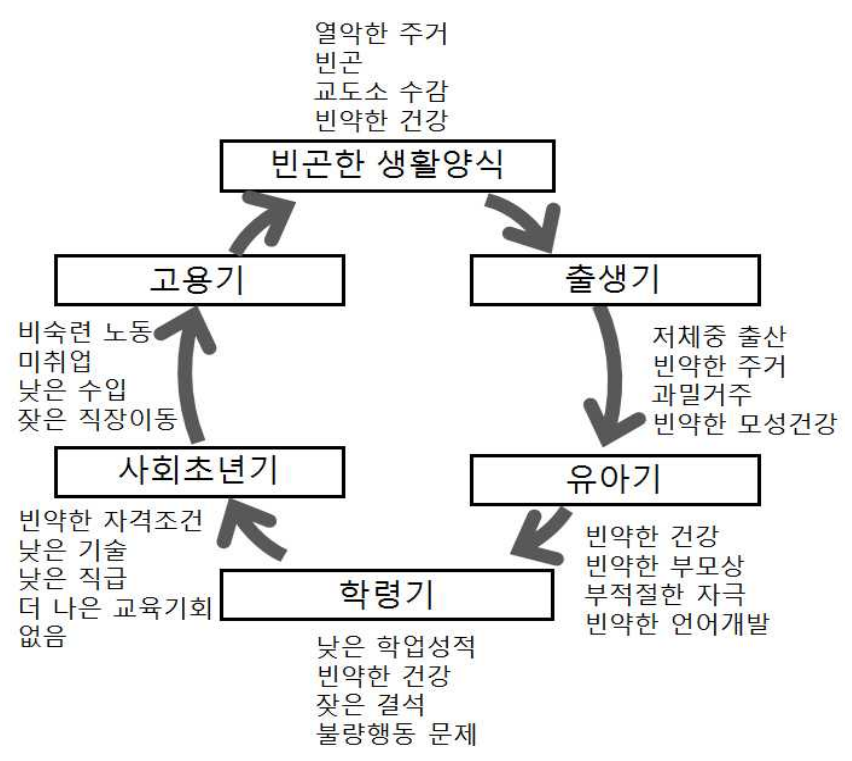

[Figure 3] Circulation of Health Inequalities(Donna Lloyd, Sallie Newell, 2004; 11)

세계인권선언(제25조, 1948)은 "모든 사람은 … 자신과 가족의 건강과 안녕에 적합한 생활수준을 누릴 권리를 가 지며 ...”라고 명시하고 있으며, $\mathrm{WHO}$ 는 1977년 세계보건 총회에서 국제 공동체 및 회원국들에게 “모든 사람을 위한 건강”을 달성하도록 하므로서 건강의 불공평성을 줄이도록 요구하였다. 말모트(Marmot, Lancet, 2005)는 "거주민의 건강이 고통 받고 있다면, 그것은 바로 사회배치에 변화가 필요하다는 징표이다“라고 하여 사회정의 차원에서 공평한 사회의 조건을 언급하였다. 이 말은 곧 불평등이 심화되고 있는 국내 건강자원의 교정이 필요하다는 의미이다.

\subsection{Relationship between the Determinants of Health and Environment}

발트레이는 사회학적인 건강의 영향요소를 5 가지로 구 분하였다(Bartley, 2004; 16).

1) 물질적 요소: 소득수준이 식품선택, 주거의 질, 공해 나 위해한 작업환경 노출 등 개인의 건강에 영향을 주는 것 과 같이 개인 혹은 집단의 물질적인 수준차가 건강의 불평 등을 만들고 개인의 건강에 영향을 미침.

2) 문화/행태적 요소: 식품선택, 흡연, 음주 등의 다른 패 턴을 가져오는 규범이나 신념, 가치관 등이 개인이나 집단 의 건강에 영향을 미침. 건강을 위해 건강에 좋은 식품선택, 금주, 금연과 같은 행태 교정이 필요함.

3) 사회 심리적 요소: 신체적 건강에 영향을 주는 집이나 직장의 상태, 조절력, 사회적 지원 등의 차이가 스트레스를 만들고 건강에 영향을 미침.

4) 생애주기 요소: 건강과 사회환경이 생애주기에 걸쳐 서로 영향을 줌. 임신 중이나 어린 시절의 건강이 생애전반 에 걸친 건강유지에 영향을 주기도 하며, 또 한편 특정 시점 에서 위험에 노출되는 것보다 생애 전반에 걸쳐 위험 노출 이 축적됨으로써 개인의 건강이 영향을 받게 됨.

5) 정치경제적 요소: 서비스 규정, 환경의 질, 사회적 관 계에 영향을 주는 정치적 변화와 재정배분 등이 건강에 영 향을 미침. 건강불평등의 가장 큰 요인으로 현재 국내에서 이슈화되고 있는 복지비용의 부담 문제나 지역차별 등 개 인이 중재할 수 없는 배경적 요인이다.

이러한 발트레이의 분류는 생애주기를 축으로 하여 정치 경제적인 요소를 배경 지원환경으로 하고, 개인의 건강수준 에 직접적인 영향을 미치는 3 가지 매개요소로서 물질적 요 소, 문화/행태적 요소 그리고 사회심리적 요소를 제시하였 다. 이 매개요소는 각각 개인의 건강에 독립적으로 영향을 미칠 뿐 아니라, 그 요소들 간에도 상호작용을 한다.

달그렌과 화이트헤드(Dahlgren and Whitehead, 1991) 는 건강에 대한 사회생태이론을 설명하면서 인간과 사람을 둘러싼 환경 그리고 질병간의 관계를 설명하는 개념도를 제시하였다(Figure 4).

이 관계도의 가장 중앙에는 연령, 성, 체질 등 유전적 속 성인 건강의 출발점으로 교정이 불가능한 개인적인 요소 가 배치되어 있다. 이 개인을 둘러싼 4 개의 층은 수정 가능 한 건강요소에 영향을 미친다. 첫 번째 층은 흡연방식, 신체 행위, 식품선택 등 개인적 행위와 생활방식으로 어떤 방식 을 선택하느냐에 따라 건강을 증진하거나 해를 끼칠 수 있 다. 두 번째 층은 가족관계, 친구관계 등 사회적이고 지역적 인 영향원으로서 나빤 상태에 대하여 지역사회 구성원에게 상호지원을 제공하거나 지역의 여건에 따라 무지원 또는 역으로 부정적인 효과도 줄 수 있다. 세 번째 층은 음식, 교 육, 작업환경, 생활과 근로조건, 고용/비고용, 식수와 위생, 
의료서비스, 주거 등으로 분류된 구체적인 환경구조를 설 명하고 있다. 표현은 다르지만, 이 환경구조에는 발트레이 의 생애주기 요소를 포함하고 있다. 예를 들어 주거는 전생 애주기 환경이며, 교육은 아동, 청소년기의 환경이다. 근로 환경은 청장년의 고용계층 주기에 해당한다. 또한 음식, 물 과 위생 등의 물리적 환경과 의료서비스를 이 환경구조에 포함시켰다. 네 번째 층은 사회경제적이고 환경적인 요소로 서 경제개발, 복지체계의 전달, 정치변화, 사회구조와 영향 력 등이다(Gillian Pascall, 2007; 413). 이 모델은 발트레이 의 분류와 맥을 같이하고 있으나, 생의학적 요소인 개인적 인 요소를 중심으로 여러 요소간의 위계를 도식화하였으며, 구체적인 환경구조를 세분하여 제시하고 있다는 차이가 있 다(Dahlgren and Whitehead, 1993, quated in Dahlgren and Whitehead, 2006; 16).

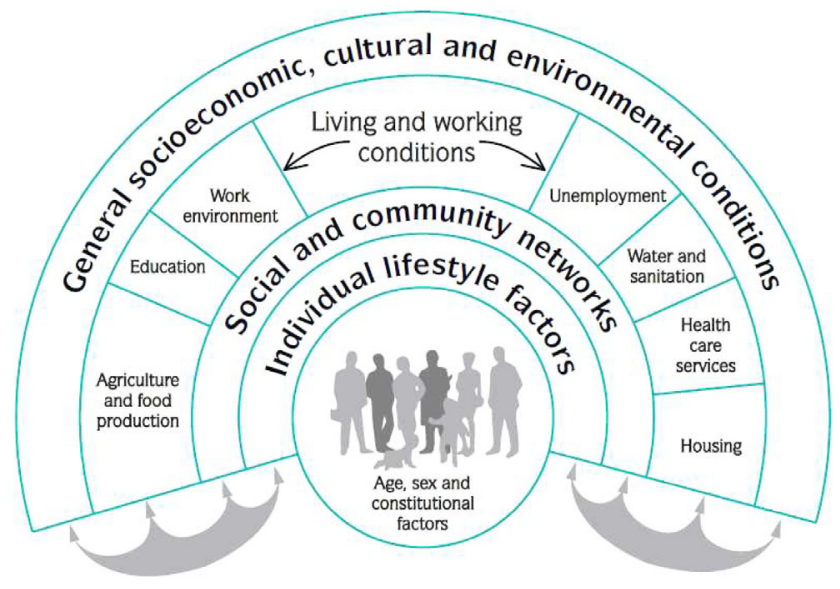

[Figure 4] The main determinants of health (Dahlgren and Whitehead, 1993, quated in Dahlgren and Whitehead, 2006; 16)

발톤과 그랜트는 달그렌과 화이트헤드의 건강결정모형 에 건축도시환경을 독립 층으로 추가하였다(Figure 5). 사 람은 중앙에 위치해 건강의 중심일 뿐만 아니라 '지속가능 한 개발'도 인간으로부터 시작되는 것을 보여주고 있으며, 인간 생활공간의 모든 측면들이 생활양식, 사회적 요인, 경 제적 요인, 행태, 건축도시환경 (building environment), 자연환경 그리고 이 모든 것을 둘러싼 지구생태계라는 위 계성을 갖고 서로 영향받고 있음을 제시하였다. 달그렌 과 화이트헤드의 모형에서 세 번째 층인 환경구조는 '행태 (activities)'라는 표현으로 사회적 요인보다는 건축도시환 경에 포함되는 영역성을 갖는 것으로 표현되어 있다.

한편, 라론데 보고서(Lalonde Report, 1974)는 홀리스 틱 모델에 근거하여 어떤 특정지역에 대한 건강의 영향요 인을 보다 함축적인 4 개 요소로 제시하고 각 요소의 영향력 을 제시하였는데, 의료시스템 $10 \%$, 유전적 요인 $20 \%$, 환경 적 요인(사회적, 물리적 환경) $20 \%$ 이며, 생활양식은 과반 인 50\%였다(Figure 6).

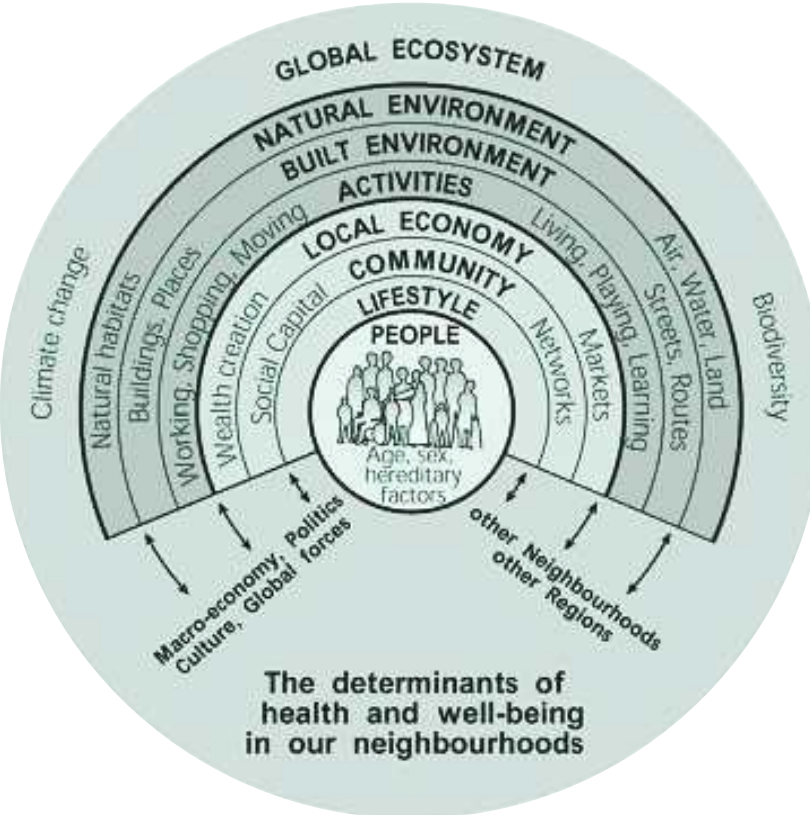

[Figure 5] Determinants of health and wellbeing(Hugh Barton and Marcus Grant, 2006; 253)

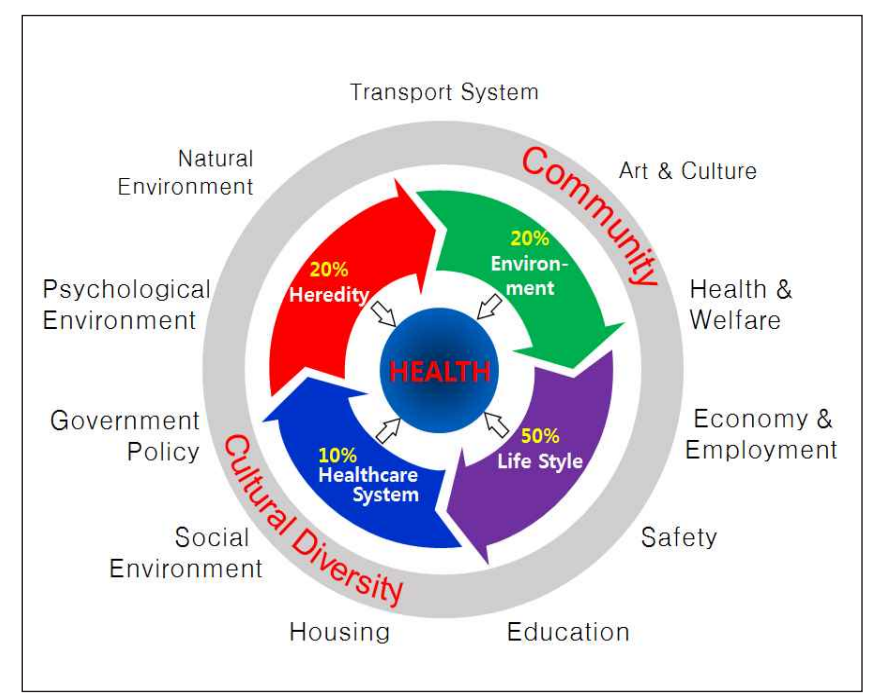

[Figure 6] The determinants of health (이부옥, 2003; 6)

우리나라의 경우, 마이클 오도넬의 연구(1999)에 따르 면, "생활양식 $52 \%$, 환경적 요인 $20 \%$, 유전적 요인 $20 \%$ 이 며, 의료서비스는 $8 \%$ 로 막대한 대국민 의료비 지출에 비해 건강에 미치는 역할이 상대적으로 작다"는 것을 보여주었 다(Michael O'donell, 1999, quoted in 남정자, 1999; 6). 이것은 건강의 문제가 전통적인 보건의료서비스에 영향을 받지만, 무엇보다 우리가 거주하면서 만들어지는 생활양식, 즉, 다양한 생활행태가 이루어지는 생활환경이 중요하다는 것을 보여주었으며, 이에 대한 중점적인 건강시스템의 보완 이 필요함을 보여주었다. 


\section{Healthy Environment Related Research Trends}

\subsection{Ecological City and Architecture}

산업혁명 이후 피폐한 도시환경에 대한 대응으로 전원도 시와 일련의 다양한 도시의 건설이 제안되어 왔으며, 1992 년 브라질 라우 유엔국제회의에서 마련된 의제 21 에서 지속 가능한 도시건설의 방향설정과 함께 도시계획의 친환경적 인 접근이 이루어졌다. 생태건축, 그린타운, 에코시티, 그린 시티, 지속가능한 도시 등은 모두 친환경 건축과 도시를 지 향하는 개념들이다.

친환경 건축은 환경 보존과 에너지절약, 자원 절약 및 재 활용, 쾌적한 주거환경 제공을 목적으로 건축자재의 생산에 서부터 건축물의 설계 및 시공, 유지 · 관리, 폐기까지 건축 물의 전 생애주기 동안 환경에 미치는 영향을 최소화하는 모든 건축 과정을 의미한다. 따라서 비록 친환경이 결과적 으로 사람의 건강을 개선하는 기능을 갖지만, 앞의 발톤과 그랜트의 건강결정요인에서 살펴본 바와 같이 인간을 그 중심에 두고 출발하여 생활양식과 사회적이고 심리적인 행 태를 거쳐 건축과 도시의 환경으로 확장하는 웰니스와 홀 리스틱 모델에 기초를 둔 건강의 개념과는 그 접근방법이 다르다고 할 수 있다. USGBC의 'LEED for Health Care'의 체크리스트로 사용되는 GGHC(the green guide for helth care)의 그린가이드 버전2.2(GGHC, 2007; 2-1 2-3)를 살펴보면(Table 1), 앞서 발트레이가 제시했던 건강의 주 요 매개요소인 사회심리적이고 문화행태적인 요소가 배제 되어 있다. 단지, 의료시설의 경우만 통합 항목을 추가하 여 건강을 고려하도록 하고 있다. 우리나라에서 시행되고 있는 친환경 건축 인증의 평가지표도 물리적이고 기술적 인 건축환경을 중심으로 규정하고 있다. 따라서 친환경 연 구 분야는 사람이 아닌 건축물의 생애주기를 중심으로 만 들어진 기술 중심의 시각으로 건강의 포괄적인 개념 중 건 강한 물리환경을 유도하는 생태학적 접근방식(Ecological Approach)이라고 할 수 있다.

\subsection{Healthy City}

1986년 세계보건기구(WHO)가 제안하여 현재 전세계 6 개 지역에서 수천 개의 도시가 참여하는 국제건강도시네트 워크가 만들어졌다. 건강도시는 건강을 주요 문제로 자각하 고 건강을 향상시키기 위해 노력하는 도시로서, 어떤 건강 도시라는 결과물이 아니라 그것을 만들어가는 과정을 말한 다. 따라서 신도시계획 뿐만 아니라 기존 도시에서도 $\mathrm{WHO}$ 도시건강지표(Table 2)를 사용하여, 그 평가수준을 점진적 으로 개선해 가면서 건강도시를 구축해갈 수 있다.

이 평가지표는 친환경연구와 비교하면, 물리적 환경뿐 만 아니라 보건 분야와 생활양식 등 대부분의 사회적 건강
[Table 1] Green Guide V.2.2 Checklists(2007)

\begin{tabular}{|c|c|}
\hline 항목 & 지표 \\
\hline \multirow{2}{*}{ 통합 } & 통합디자인프로세스(필수) \\
\hline & 건강 미션 진술서/ 프로그램(필수) \\
\hline \multirow{6}{*}{$\begin{array}{l}\text { 지속가능한 } \\
\text { 부지 }\end{array}$} & 건설행위 오염방지(필수) \\
\hline & 부지선정 \\
\hline & 개발밀도, 지역사회와의 연결성 \\
\hline & $\begin{array}{l}\text { 기존지역 재개발: 기반시설/거주지 개선 정도/장래 위험 최 } \\
\text { 소화 }\end{array}$ \\
\hline & $\begin{array}{l}\text { 대안 교통수단(공공교통 접근성, 자전거 보관 및 수선실 설 } \\
\text { 치, 저배출과 고효율 차량, 주차용량) }\end{array}$ \\
\hline & $\begin{array}{l}\text { 부지개발 : 오픈스페이스와 서식지의 보호와 복원, 건폐율 } \\
\text { 개발 최소화, 구조화된 주차 }\end{array}$ \\
\hline \multirow{5}{*}{$\begin{array}{l}\text { 지속가능한 } \\
\text { 부지 }\end{array}$} & 우수디자인(양과 질 관리) \\
\hline & 열섬효과 \\
\hline & 광공해 감소 \\
\hline & $\begin{array}{l}\text { 자연으로의 연결: 휴식을 위한 옥외 장소, 환자들의 외부로 } \\
\text { 의 접근성 }\end{array}$ \\
\hline & 지역사회 오염방지: 공기오염 방지, 폐수/폐유 유출 \\
\hline \multirow{3}{*}{$\begin{array}{l}\text { 수자원의 } \\
\text { 효율성 }\end{array}$} & 의료장비 냉각에 음용수 사용(필수) \\
\hline & 효율적인 물사용 조경: 잡용수 사용/ 수로 미설치 \\
\hline & $\begin{array}{l}\text { 음용수 사용 절감(측정 및 인증, 생활용수, 물 재활용과 건 } \\
\text { 물시스템 구축 }\end{array}$ \\
\hline \multirow{10}{*}{$\begin{array}{l}\text { 에너지 } \\
\text { 및 공기 }\end{array}$} & 건물 에너지 시스템의 기본 시운전 시험(필수) \\
\hline & 최소 에너지 성능(필수) \\
\hline & 기본 냉매 관리(필수) \\
\hline & 에너지 성능 적정화 \\
\hline & 대지내 재생가능한 에너지 사용 \\
\hline & 시운전 강화 \\
\hline & 냉매 관리 강화 \\
\hline & 에너지 효율 측정과 검증 \\
\hline & 녹색 발전기술 - 세분화 \\
\hline & 장비의 효율성 \\
\hline \multirow{10}{*}{$\begin{array}{l}\text { 재료 및 } \\
\text { 자원 }\end{array}$} & 재활용 자재의 수집과 보관(필수) \\
\hline & 수은제거(필수) \\
\hline & 건물 재활용 \\
\hline & 건설 폐기물 관리 \\
\hline & 건설관리: 부지 및 자재, 유틸리티 및 가스배출관리 \\
\hline & 지속가능한 자재 \\
\hline & PBT 제거: 다이옥신, 수은, 납 및 카드뮴 \\
\hline & 가구 및 의료비품: 자원재사용, 재료, 생산, 이동 및 재활용 \\
\hline & 구리 절감 \\
\hline & 자원사용: 융통성, 내구성 디자인 \\
\hline \multirow{12}{*}{$\begin{array}{l}\text { 환경의 } \\
\text { 질 }\end{array}$} & 최소한의 실내 공기 질 수행(필수) \\
\hline & 담배연기 관리(필수) \\
\hline & 위해한 재료 제거와 밀폐(필수) \\
\hline & 외기유입 감시 \\
\hline & 자연환기 \\
\hline & 환경의 질 관리: 공사기간 중, 입주 전 \\
\hline & $\begin{array}{l}\text { 오염물질 저배출 자재: 인테리어 접착제/밀봉재, 벽과 천장 } \\
\text { 마감, 바닥마감, 합성목재와 단열재, 가구 및 비품 }\end{array}$ \\
\hline & 화학성분 및 오염원의 제어: 옥외, 실내 \\
\hline & 시스템 제어력 : 조명, 온열 안락감 \\
\hline & 온열 안락감 \\
\hline & $\begin{array}{l}\text { 채광 및 조망: 일조, 자연과의 연결(옥내 휴게장소), 조명과 } \\
\text { 신체리듬 }\end{array}$ \\
\hline & $\begin{array}{l}\text { 음향환경:외부소음, 음향마감, 실내소음 수준, 소리차단, 호 } \\
\text { 출설비, 건물진동 }\end{array}$ \\
\hline \multirow{2}{*}{$\begin{array}{c}\text { 창의성/ } \\
\text { 디자인과정 }\end{array}$} & 창의적 디자인 \\
\hline & 건강, 의료의 질과 생산성 수행정도: 연구계획 \\
\hline
\end{tabular}

* 진한글자: LEED-NC와 비교해 LEED-HC에만 추가된 항목

* 이탤릭체: LEED-NC보다 세분화 또는 축소된 항목 


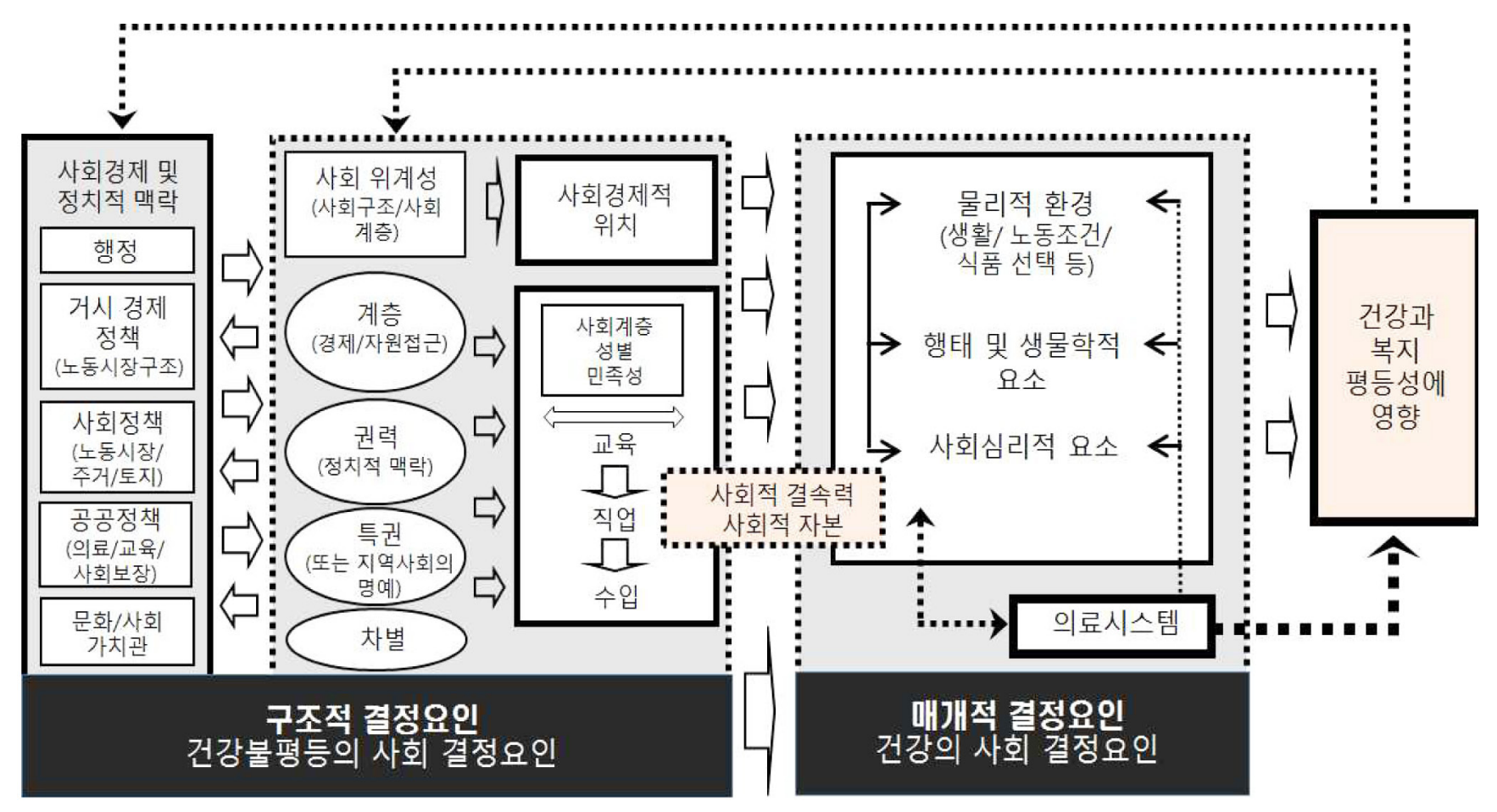

[Figure 7] Conceptual Framework of The Commission on Social Determinants of Health (WHO CSDH, 2011; 6)

[Table 2] WHO City Health Profiles (WHO Regional Office for Europe, 1995: 41-56)

\begin{tabular}{|c|c|c|}
\hline 구분 & 항목 & 지표 \\
\hline 1 & 인구 & $\begin{array}{l}\text { - 도시의 크기 } \\
\text { - 인구구조 }\end{array}$ \\
\hline 2 & 보건실태 & - 인구통태 통계 - 질병구조 \\
\hline 3 & $\begin{array}{l}\text { 라이프 } \\
\text { 사이클 }\end{array}$ & $\begin{array}{l}\text { - 흡연 · 음주 · 약 남용 · 운동 } \\
\text { - 다이어트 }\end{array}$ \\
\hline 4 & 주거 & $\begin{array}{l}\text { - 노숙자수 · 주거의 물리적 특징 } \\
\text { - 인구밀도 }\end{array}$ \\
\hline 5 & $\begin{array}{l}\text { 사회경제적 } \\
\text { 조건 }\end{array}$ & $\begin{array}{l}\text { - 교육 - 고용 - 수입 · 범죄와 폭력 } \\
\text { - 사회적 참여 }\end{array}$ \\
\hline 6 & $\begin{array}{l}\text { 물리적 } \\
\text { 환경 }\end{array}$ & $\begin{array}{l}\text { - 공기질 · 수질 · 상하수 서비스 } \\
\text { • 소음공해 • 방사능 • 오픈스페이스 } \\
\text { - 짐승/곤충 피해 - 식품의 질 }\end{array}$ \\
\hline 7 & 형편성 & $\begin{array}{l}\text { - 도시내 여러 다른 수준의 건강과 } \\
\text { 라이프사이클 }\end{array}$ \\
\hline 8 & $\begin{array}{l}\text { 사회물리적 } \\
\text { 인프라 }\end{array}$ & $\begin{array}{l}\text { - 교통 - 통신 · 도시재생 - 도시계획 } \\
\text { - 훈련을 통한 기회창출 } \\
\text { - 지역사회의 발전유형 - 사회적 고립 }\end{array}$ \\
\hline 9 & $\begin{array}{l}\text { 보건정책과 } \\
\text { 서비스 }\end{array}$ & $\begin{array}{l}\text { - 질병예방 정책과 서비스 · 교육정책과 } \\
\text { 서비스 - 환경정책과 서비스 }\end{array}$ \\
\hline
\end{tabular}

결정요소를 포괄하고 있다. 그러나 물리적 환경을 대상으로 하는 친환경연구에 비하여 인구 및 사회적인 요소들을 어 떻게 구체적인 건축 또는 도시환경으로 해석하고 연관시킬 것인지 어려움이 있다.
한편, $\mathrm{WHO}$ 의 사회건강결정위원회 (Commission on Social Determinants of Health)는 건강을 결정하는 중재 모델을 제시하였다(Figure 7). 이 모델은 건강의 결정요인 을 크게 구조적 중재요인, 매개적 중재요인으로 구분하였 다.

1) 구조적 중재요인: 사회적, 경제적, 정치적 메커니즘은 개인의 사회 경제적 위치에 형성을 미치고, 개인은 소득, 교 육, 직업, 성별, 인종/민족 등의 요인에 따라 계층화된다. 이 러한 사회 경제적 위치는 사회계층 내 개인의 위치를 반영 하는 건강상태에 따른 특정 건강결정요인을 형성하게 한다. 건강의 불평등을 초래하는 사회의 구조적 요인들이다.

2) 매개적 중재요인: 사회구조적 요인은 건강의 매개결 정요인에 영향을 주게 되고, 결국 개인의 건강에 최종 결과 로서 나타난다. 건강의 매개결정요인은 물질환경, 사회심리 환경, 행태 및 생물학적 환경 그리고 보건의료시스템으로 분류하고 있다.

여기서 구조요인은 광역적인 맥락으로 개인이 직접 중재 하는 것이 어렵기 때문에 건강의 직접적인 결정요소인 매 개중재요소를 변화시키는 것이 건강증진의 기본 목적이 된 다. 이것은 생물학적인 요인을 제외하면 크게 물리환경, 사 회심리환경 그리고 행태환경이 된다.

또한 건강도시연맹 (AFHC; WHO서태평양지부)은 지역 의 건강증진을 위한 기본 틀로서 '장' 접근법을 제시하였다 (Table 3). 
[Table 3] Approaches for Healthy City in AFHC (AFHC, 2006; 21)

\begin{tabular}{|c|c|c|c|}
\hline 구분 & 건강한 장 & 건강한 인구 & 건강한 생활양식 \\
\hline 구성 & $\begin{array}{l}\text { - 건강한 도시 } \\
\text { - 건강한 섬 } \\
\text { - 건강한 마을 } \\
\text { - 건강한 산업장 } \\
\text { - 건강한 시장 } \\
\text { - 건강한 학교 } \\
\text { - 건강한 병원 }\end{array}$ & $\begin{array}{l}\text { - 아동 및 청소년 } \\
\text { 건강 } \\
\text { - 청소년 건강 및 } \\
\text { 개발 } \\
\text { - 생식 건강 } \\
\text { - 노화와 건강 }\end{array}$ & $\begin{array}{l}\text { - 영양 } \\
\text { - 금연 발의안 } \\
\text { - 식품 안전 } \\
\text { - 가족 계획 } \\
\text { - 신체 활동 } \\
\text { - 약물 남용 예방 } \\
\text { - 가정 폭력 예방 } \\
\text { - 상해 예방 } \\
\text { - 정신 건강 증진 }\end{array}$ \\
\hline 개념 & $\begin{array}{l}\text { - 안전한 물리 } \\
\text { 환경 }\end{array}$ & $\begin{array}{l}\text { - 예방 및 보건 } \\
\text { 의료 서비스 }\end{array}$ & $\begin{array}{l}\text { - 행태교정 및 } \\
\text { 건강 지원환경 }\end{array}$ \\
\hline
\end{tabular}

이것은 건축 및 도시환경 연구에 매우 유용한 도구를 제 공한다. 3 가지 큰 연구의 틀을 제공하는데, (1) 건강한 장 : 사람들이 살아가고, 일하고, 배우며 그리고 노는 현장에서 의 건강 증진(안전한 물리환경) (2) 건강한 인구 : 생애 주기 전체를 통해 연령별 특정 발전단계와 관련된 위험 예방(예 방 및 보건의료서비스) (3) 건강한 생활양식 : 개인과 지역 사회가 건강하지 못한 생활양식, 행태 그리고 환경에 의해 유발되는 위험 교정 (행태교정 및 건강 지원환경)이다.

이것을 $\mathrm{WHO}$ 사회건강결정위원회의 건강결정모델과 비 교하면, 건강한 장은 안전한 물리환경이며, 건강한 인구는 예방 및 보건의료시스템, 그리고 건강한 생활양식은 생애주 기에 따른 행태교정 및 건강지원환경의 구축이다. 이러한 환경들의 포괄적인 구축을 통해, 개인의 건강을 증진시킬 수 있으며, 이렇게 증진된 건강은 피드백되어 개인이 직접 적으로 영향을 줄 수 없는 사회의 구조적인 건강결정요인 을 개선하게 되어 건강의 선순환을 이끌게 된다.

\subsection{Healing Environment \& Evidence-Based Design}

코날스키(Konarski K.)에 따르면, "인간은 창조적이고 혁신적이며, 예측이 불가능한 존재로서, 우리의 일상생활 속에 질병으로 진행되는 과정과 건강을 증진하는 과정이 공존하고 있다"고 한다. "그 과정은 사회정신적인 요소, 생 활양식, 감정과 경험 등에 의해 이루어진다"(Konarski K. 1992, quoted in Alan Dilani, 2001; 16).

또한 레비(Levi L.)의 스트레스 이론과 사회심리적인 매 개질병 이론에 따르면, "물리환경은 사회 조직, 구조 및 기 능을 생성하는 출발점으로서, 이 환경의 사회정신적 자극에 대하여 우리 몸에 내재된 생물정신적 프로그램이 생리적이 고 심리적인 반응을 일으킨다. 이 과정에서 각 개인의 스트 레스를 일으키는 메카니즘이 생겨난다“고 한다. "어떤 특정 한 상황에서 이 메카니즘은 질병의 전조현상을 보이고 또 한 질병으로 이끌게 되는데, 이에 대응한 건강요소와 사회 심리적인 지원환경(치유환경)을 통해, 이 과정의 진행을 막
을 수 있다"고 하였다(Konarski K. 1992, 1999, quoted in Alan Dilani, 2001; 20).

TEXAS A\&M 대학의 울릭 (Roger S. Ulrich) 교수는 치유 환경의 최대의 장애는 '스트레스'라고 말하면서 “의료시설 디자인은 효율성, 시장성, 경제성 등의 제반조건 이상으로 치유환경 설계가 중요하다. 이를 통해 환자의 제반 스트레 스를 줄일 수 있고, 약품과 기타 의학기술의 치유효과를 높 이며, 회복과정을 촉진시킬 수 있다”고 하였다. 반면, “비치 유환경은 스트레스에 대응할 수 없을 뿐만 아니라 그 자체 가 스트레스원이 되어 질병의 부담을 가중시키므로 의료시 설의 신축과 리모델링에서 정신적 치유환경 구축에 우선순 위를 주어야 한다."고 하였다(Roger S. Ulrich, 1984: 420421).

[Table 4] Summary of the Relationships Between Design Factors and Healthcare Outcomes(Roger S. Ulrich et al., 2008; 53)

\begin{tabular}{|c|c|c|c|c|c|c|c|c|c|c|}
\hline $\begin{array}{r}\text { 디자인전략 } \\
\& \text { 환경적 } \\
\text { 중재 } \\
\text { 의료성과 }\end{array}$ & $\begin{array}{l}\text { 개인 } \\
\text { 병실 }\end{array}$ & $\begin{array}{l}\text { 자 } \\
\text { 연 } \\
\text { 채 } \\
\text { 광 }\end{array}$ & $\begin{array}{l}\text { 적 } \\
\text { 절 } \\
\text { 한 } \\
\text { 조 } \\
\text { 명 }\end{array}$ & \begin{tabular}{l|} 
자 \\
연 \\
조 \\
망
\end{tabular} & $\begin{array}{l}\text { 병 } \\
\text { 실 } \\
\text { 가 } \\
\text { 족 } \\
\text { 공 } \\
\text { 간 }\end{array}$ & \begin{tabular}{|l} 
소 \\
음 \\
감 \\
소 \\
마 \\
감
\end{tabular} & $\begin{array}{c}\text { 천 } \\
\text { 장 } \\
\\
\text { 리 } \\
\text { 프 } \\
\text { 트 }\end{array}$ & $\begin{array}{c}\text { 간 } \\
\text { 호 } \\
\text { 공 } \\
\text { 간 } \\
\text { 배 } \\
\text { 치 }\end{array}$ & $\begin{array}{c}\text { 분 } \\
\text { 산 } \\
\text { 물 } \\
\text { 품 } \\
\text { 공 } \\
\text { 급 }\end{array}$ & $\begin{array}{l}\text { 다 } \\
\text { 용 } \\
\text { 도 } \\
\text { 병 } \\
\text { 실 }\end{array}$ \\
\hline 감염 감소 & - & & & & & & & & & \\
\hline 의료 사고 감소 & - & & - & & & - & & & & - \\
\hline 환자 낙상 감소 & - & & - & & - & - & & - & & - \\
\hline 통증 감소 & & - & - & - & & - & & & & \\
\hline 환자 수면 개선 & - . & - & - & & & - & & & & \\
\hline $\begin{array}{l}\text { 환자 스트레스 } \\
\text { 감소 }\end{array}$ & - & - & - & $-\square$ & - & $\square$ & & & & \\
\hline 우울해소 & & $\square=$ & $=0$ & - & ! & & & & & \\
\hline 입원기간 감소 & & - & - & - & & & & & & - \\
\hline $\begin{array}{l}\text { 환자 프라이 } \\
\text { 버시 개선 }\end{array}$ & - & & & & - & - & & & & \\
\hline $\begin{array}{l}\text { 환자, 가족 간 } \\
\text { 대화 증진 }\end{array}$ & - & & & & . & . & & & & \\
\hline $\begin{array}{l}\text { 사회적 지원 } \\
\text { 개선 }\end{array}$ & . & & & & . & & & & & \\
\hline $\begin{array}{l}\text { 환자 } \\
\text { 만족감 개선 }\end{array}$ & . & - & - & - & - & - & & & & \\
\hline $\begin{array}{l}\text { 의료진 } \\
\text { 상해 감소 }\end{array}$ & & & & & & & - - & & & - \\
\hline $\begin{array}{l}\text { 의료진 } \\
\text { 스트레스 감소 }\end{array}$ & " & " & - & - & & " & & & & \\
\hline $\begin{array}{l}\text { 의료진 } \\
\text { 효율성 증대 }\end{array}$ & . & & " & & & " & & " & " & " \\
\hline $\begin{array}{l}\text { 의료진 } \\
\text { 만족감 개선 }\end{array}$ & 口 & " & " & " & & " & & & & \\
\hline
\end{tabular}

- 검증된 직접, 간접적 실험연구에 기반한 요소

- - 매우 강한 근거에 기반한 요소 
울릭은 또한 사이언스지에 “자연환경을 바라보는 창을 가진 병실이 벽돌벽을 바라보는 창을 가진 병실보다 수술 환자에게 더 치유적이다.”라는 실험결과를 보고하였으며, 또 다른 실험에서는 "만성무료증 환자는 자연환경보다 오 히려 활기찬 시가지 풍경이 더 치유적일 수 있다."라고 하 였다(Roger S. Ulrich, 1984: 420-421). 이것은 치유환경 의 조성뿐만 아니라 동시에 근거기반디자인 (EvidenceBased Design)의 중요성을 말한 것이다. 일반적으로 자연 풍경은 치유에 좋을 것이라고 생각하지만, 상황에 따라 다 르다는 점을 보여주었다. 해밀톤은 디자이너들이 의료환경 을 조성하는데 있어 주관적인 접근방법 보다는 구체적이고 객관적인 연구결과나 정보를 바탕으로 디자인 결정을 하는 것이 중요하다.”고 하였다(Hamilton K., 2003: 18 26).

근거기반디자인은 디자인 전략이나 환경적 중재에 대한 의료적 성과를 도출한 실험적이고 실증적인 연구로 검증된 근거에 기반하는 것으로 우울해소, 스트레스 등과 같은 무 형의 사회심리적인 환경요소에 대하여 효과적인 물리환경 이나 디자인 요소를 적용하도록 하는 유용한 번역도구가 될 수 있다(Table 4). 이런 맥락에서 건강을 결정하는 중재 모델에서 일련의 사회심리적이고 물리적인 환경요인은 치 유환경과 근거기반디자인의 관점에서 검토되어야 한다.

\section{Result; Integrated Research Model for Healthy Urban \& Architectural Environment}

\subsection{Concept of Proposed Model}

건강의 개념은 질병의 예방과 치료와 같은 의료의 개념 을 넘어서서 질병의 위험에 노출되어 있는 사람이나 건강 한 사람이 거주하는 우리의 일상생활 환경과 도시환경의 구석구석까지로 확장되고 있다. 따라서 개인의 건강은 건강 스펙트럼을 사회구조 전반으로 확장하는 포괄적인 개념으 로 접근해야 한다.

건강 연구의 대상으로서 사람은 건강한 사람 질병 위험 에 노출된 사람 $\longrightarrow$ 질병을 가졌지만 일상생활 환경에 있는 사 람 $\longrightarrow$ 질병으로 의료기관에 입원한 사람 $\longrightarrow$ 질병의 결과로 나 타난 장애인(신체능력이 저하된 노인 포함)으로 분류하고, 이에 대응하는 건강개념은 안전과 위생 $\rightarrow$ 건강증진 $\longrightarrow$ 질병 예방 $\longrightarrow$ 진단 및 치료 $\rightarrow$ 재활의 위계성을 부여한다. 이와 같은 포괄적인 건강스펙트럼을 연구의 궁국적인 목표인 환경과 연계하여 3 가지의 건강환경으로 분류하고(Figure 8), 여기 에 건강도시연맹의 “장 접근법”을 도입한다(Figure 9).

1) 안전하고 위생적인 정주(건축/도시)환경

건강한 사람이 정주하는 환경으로서 발톤과 그랜트의 건 강결정모형에서 가장 외곽에 위치하는 자연 및 정주환경에 해당한다. 건축도시분야에서 연구되는 친환경 연구로서 생
태학적 방법론을 적용한다. 이미 여러 종류의 건물환경에 대한 인증 프로그램을 시행하고 있으므로 그 개념과 내용 을 차용하면 되지만, 앞서 살펴본 바와 같이 친환경 연구가 물리적이고 기술적인 내용을 중심으로 기술하고 있으므로, 치유환경과 근거기반디자인의 개념으로 재검토해야 한다.

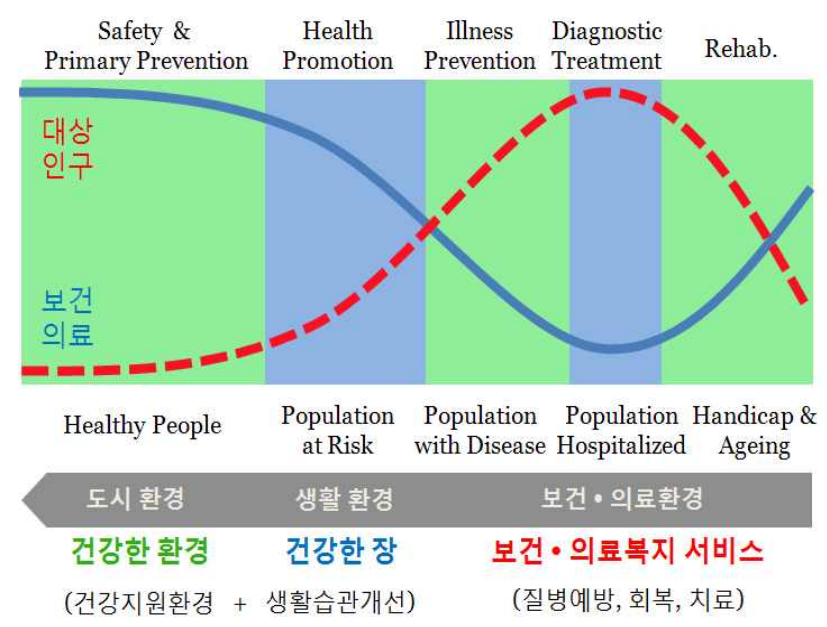

[Figure 8] Integration Concept of Health Spectrum and Urban \& Architectural Environment

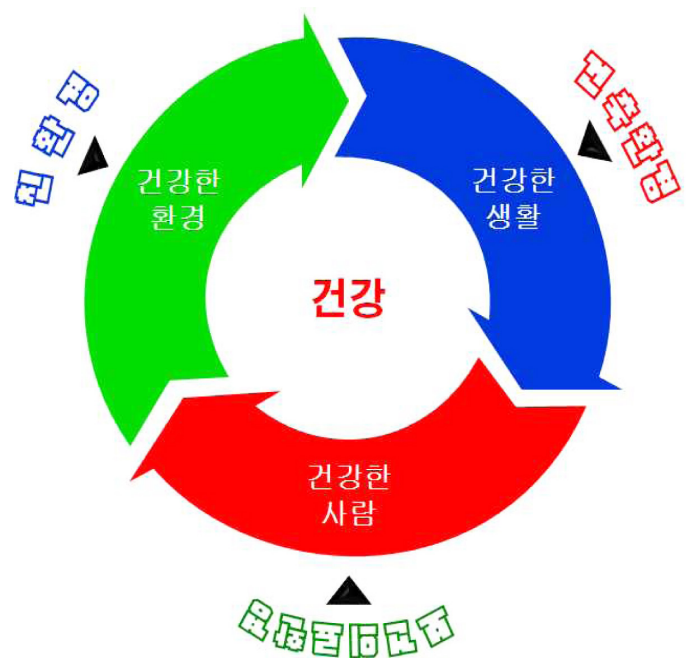

[Figure 9] Three Factors for Healthy Environment

\section{2) 건강증진을 위한 일상생활환경}

건강증진이 필요한 일상생활환경으로 우리가 태어나서, 배우고, 일하며, 늙어가는 모든 생활환경에서 건강을 확보 함으로서 개인과 지역사회가 건강에 해로운 생활양식과 생 활행태 그리고 환경에 의해 유발되는 위험을 개선해 나갈 수 있다. 행태와 건물환경 (발톤과 그랜트의 건강결정모형), 생활양식(라론데 보고서)에 해당하는 영역으로 건강에 미 치는 영향 면에서 가장 중요하며, 가장 중점적으로 연구해 야 할 부분이다. 생애주기에 따른 건물환경(주거/학교/직 
장 등)의 건강건축계획이 필요하며, 물리환경, 문화/행태환 경 그리고 심리환경적 연구(발트레이와 $\mathrm{WHO} \mathrm{CSDH}$ 의 매 개 건강결정요인)가 필요하다. 보건의료분야에서 발전된 치유환경 및 근거기반디자인 방법론을 도입한다.

\section{3) 보건 및 의료복지 환경}

질병예방(공중보건), 진단치료(의료환경), 재활을 포괄 하는 영역으로 전통적인 보건의료서비스의 영역이다. 직접 적인 의료행위를 수행하는 의료복지시설을 제외하면, 일반 건축과 도시공간에서는 언제 어디서나 가능한 서비스의 접 근성이 가장 중요하다. 기존의 치유환경 및 근거기반디자인 이론을 사용한다.

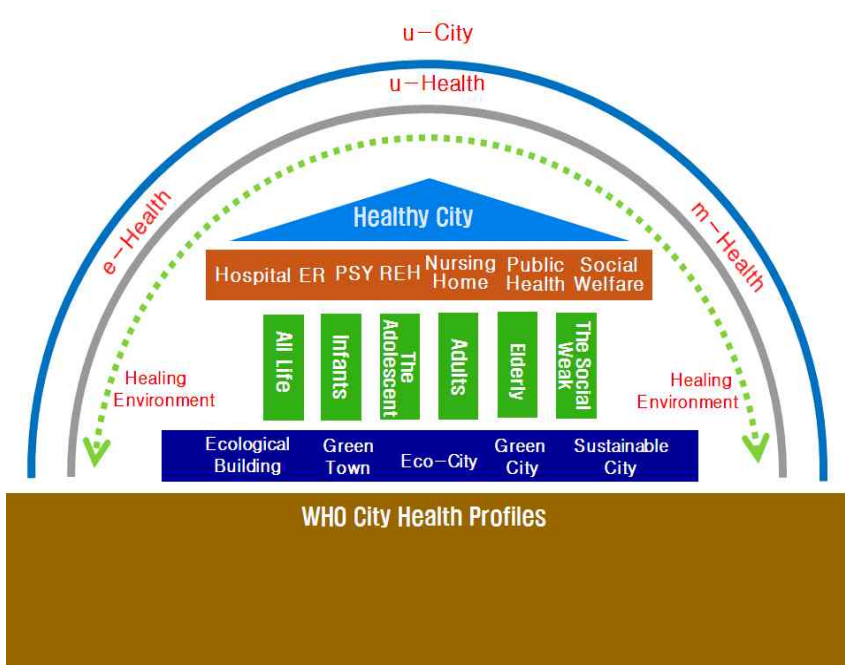

[Figure 10] The Image of Healthy City and Architecture

이러한 건강스펙트럼의 확장과 연구모델을 적용한 건강 한 건축도시의 이미지(Figure 10)는 기본적으로 WHO 건 강도시지표를 기반으로 하고, 안전과 위생을 위한 생태환경 도시의 기반위에 건강증진이 필요한 생애주기별 생활환경 의 지주가 세워진다. 생애주기별 생활환경은 사회적 약자를 위한 시설까지 포함한다. 마지막으로, 모든 생활환경과 도 시공간에 접근 가능한 보건의료서비스 환경이 그 위에 얹 혀 지고 연결된다. 도시는 치유환경으로 덮여지고, 서비스 의 지원이 항상 가능한 유비쿼터스 환경으로 감싸여진다.

\subsection{Environment for the safety and the prevention}

친환경은 건강을 위한 기본적인 구성요소이다. 전술한 바와 같이 그린시티, 친환경건축 기준 등 평가지표가 있으 며, 친환경적 요소기술 및 기법이 지속적으로 개발되고 있 다. 따라서 친환경에서 제시하는 여러 지표들에 대하여 직 접효과, 건강에 대한 영향 등을 면밀히 검토하여 치유환경 적이고, 근거기반의 건축/도시환경이 구축되어야 한다.
[Table 5] Urban Environment for the Safety and the Prevention

\begin{tabular}{|c|c|c|c|c|}
\hline $\begin{array}{l}\text { 환경 } \\
\text { 요소 }\end{array}$ & 항목 & 직접효과 & $\begin{array}{c}\text { 건강에 미치는 } \\
\text { 효과 }\end{array}$ & $\begin{array}{l}\text { 건강을 위한 } \\
\text { 도시계획 }\end{array}$ \\
\hline 교통 & 소음 & $\begin{array}{l}\text { - 비행기 } \\
\text { - 열차 } \\
\text { - 도로교통 }\end{array}$ & $\begin{array}{c}\text { - 청력감소, 의 } \\
\text { 사소통방해 } \\
\text { - 불쾌감, 수 } \\
\text { 면/행동장애 } \\
\text { - 심혈관/생리/ } \\
\text { 정신건강 }\end{array}$ & $\begin{array}{l}\text { - 환경친화적 } \\
\text { 청정교통 }\end{array}$ \\
\hline \multirow{5}{*}{$\begin{array}{c}\text { 에너지 } \\
\text { 공기/물 } \\
\text { 소음 } \\
\text { 폐기물 } \\
\text { 생물 } \\
\text { 다양성 }\end{array}$} & $\begin{array}{l}\text { 대기 } \\
\text { 오염 }\end{array}$ & $\begin{array}{l}\text { - 미세먼지 } \\
\text { - 일산화탄 } \\
\quad \text { 소 } \\
\text { - 아황산가 } \\
\quad \text { 스 }\end{array}$ & $\begin{array}{c}\text { - 기침, 기관지 } \\
\text { - 심부전, 만성 } \\
\text { 기침, 활동제 } \\
\text { 한, 호흡질환 } \\
\text { - 뇌혈관질환, } \\
\text { 암발생, 급사 }\end{array}$ & $\begin{array}{c}\text { - 공기오염과 소음 } \\
\text { 대처방안 개발 }\end{array}$ \\
\hline & $\begin{array}{l}\text { 교통 } \\
\text { 사고 }\end{array}$ & $\begin{array}{l}\text { - 자동차 } \\
\text { - 보행 } \\
\text { - 자전거 } \\
\text { - 대중교통 }\end{array}$ & $\begin{array}{l}\text { - 상해 } \\
\text { - 사망 } \\
\text { - 정신적 피해, } \\
\quad \text { 재활 }\end{array}$ & $\begin{array}{l}\text { - 교통사고에 대처/ } \\
\text { 도로안전 활동 } \\
\text { - 감속도로 설계/운 } \\
\text { 전자의 태도변화 } \\
\text { 등 } \\
\text { - 보행이 안전한 순 } \\
\quad \text { 환체계 }\end{array}$ \\
\hline & $\begin{array}{l}\text { 물리적 } \\
\text { 활동 }\end{array}$ & $\begin{array}{l}\text { - 자전거타 } \\
\quad \text { 기 } \\
\text { - 걷기 } \\
\text { - 인라인타 } \\
\quad \text { 기 }\end{array}$ & \begin{tabular}{|l} 
- 긍정적 사고 \\
- 질병/사망률 \\
감소 \\
- 만성질환감소 \\
- 우울증 억제, \\
정신질환치 \\
료, 암발생 \\
감소
\end{tabular} & $\begin{array}{l}\text { - Active Living } \\
\text { - well-lit 산책로, 조 } \\
\text { 깅코스, 자전거 도 } \\
\text { 로 제공 } \\
\text { - 도보, 조깅, 사이클 } \\
\text { 링, 인라인 스케이 } \\
\text { 트 등의 다기능 보 } \\
\text { 도 설비 }\end{array}$ \\
\hline & 고립 & $\begin{array}{l}\text { - 접근성저 } \\
\quad \text { 하 } \\
\text { - 교통량증 } \\
\quad \text { 가 } \\
\text { - 도로/철도 } \\
\quad \text { 분리 }\end{array}$ & $\begin{array}{l}\text { - 지역분리, 소 } \\
\text { 통저해 } \\
\text { - 사회적 접촉 } \\
\text { 감소로 스트 } \\
\text { 레스증대 } \\
\text { - 질병감수성 } \\
\text { 저하 }\end{array}$ & $\begin{array}{c}\text { - 모든 시민들에게 } \\
\text { 근로, 여가시설, 상 } \\
\text { 점 그리고 기타 시 } \\
\text { 설기관에 대해 도 } \\
\text { 보 · 자전거에 의한 } \\
\text { 접근성 강화 } \\
\text { - 무장애 공간 }\end{array}$ \\
\hline & 불평등 & $\begin{array}{l}\text { - 교통 } \\
\text { 접근성 } \\
\text { 불평등 }\end{array}$ & $\begin{array}{l}\text { - 교통접근성 } \\
\text { 저하 } \\
\text { - 경제적,신체 } \\
\text { 적 취약자의 } \\
\text { 서비스 접근 } \\
\text { 성저하 }\end{array}$ & $\begin{array}{c}\text { - 접근성이 용이한 } \\
\text { 대중교통수단 이용 } \\
\text { - 접근성을 고려한 } \\
\quad \text { 시설 및 서비스 } \\
\text { - 무장애 공간 }\end{array}$ \\
\hline
\end{tabular}

[Table 5]는 정주환경의 친환경 계획요소를 정리한 예시 이다. 예를 들어, 교통 요소에는 소음, 대기오염, 교통사고, 물리적 활동, 고립, 불평등의 하부 요소가 있고 각각의 요소 에 대하여 건강의 효과와 건강계획요소를 제시하고 있다. 물론 실제 연구에서는 더욱 자세한 접근이 필요하다. 이와 같은 방식으로 에너지, 공기, 물, 소음, 폐기물, 생물다양성 등의 환경요소에 대하여 하부요소의 분류와 건강계획요소 
를 연구해야 한다.

\subsection{Building Environment for Life Cycle}

생애 주기 전체를 통해 사람들이 살아가는 현장에 맞추 어 건강을 증진하는 환경을 조성하는 것이며, 개인과 지역 사회가 불건강한 생활양식, 행태 그리고 환경에 의해 유발 되는 위험을 변경시킬 수 있게 하는 것이다. 건축적 차원에 서 영유아기, 청소년기, 청장년기, 노년기, 전생애주기 그리 고 사회적 약자를 위한 시설과 같은 생애주기별 시설에 대 한 치유환경과 근거중심의 접근방식이 필요하며, 다학제적 인 연구결과들에 대하여 건축계획적 검토가 이루어져서 자 료화되는 과정을 지속적으로 반복하여야 한다(Table 6).

[Table 6] Daily Life Environment for Health Promotion

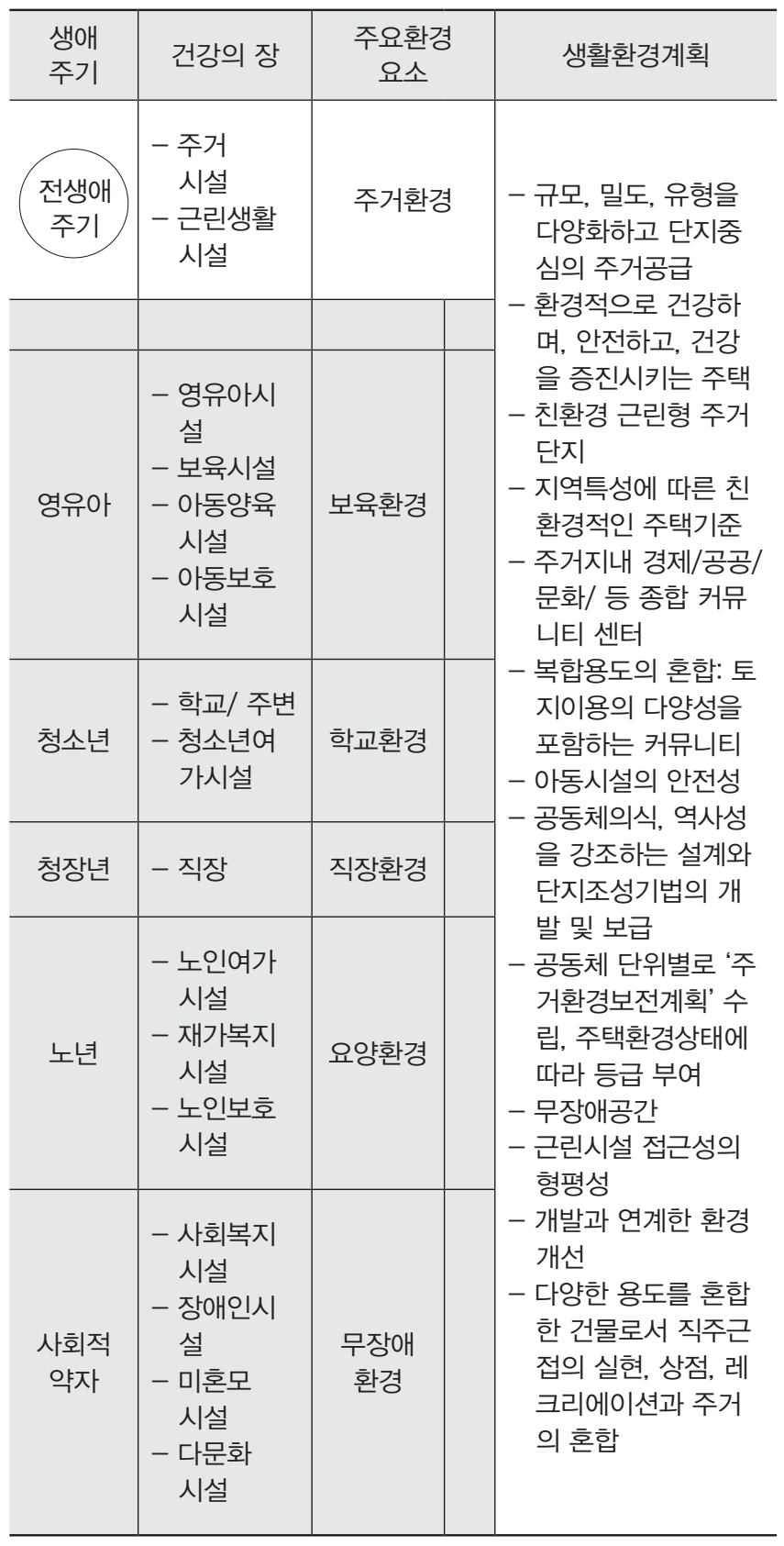

[Table 7] Health Care Environment for Accessibility

\begin{tabular}{|c|c|c|c|}
\hline $\begin{array}{l}\text { 보건의료 } \\
\text { 환경 }\end{array}$ & \multicolumn{2}{|r|}{ 계획요소 } & \multirow{2}{*}{$\begin{array}{l}\text { 보건의료서비스계획 } \\
\\
\text { - 의료전달체계 } \\
\text { - 사회복지전달체계 } \\
\text { - 도시/지역 네트워크 }\end{array}$} \\
\hline $\begin{array}{l}\text { 병원 } \\
\text { 횐경 }\end{array}$ & 접근성 & $\begin{array}{l}\text { - 의료복지시설 } \\
\text { 의 위치/수 } \\
\text { - 의료보호 } \\
\text { - 원격진료 }\end{array}$ & \\
\hline & 비용 & - 비용 효율성 & - 역할분담, 비용 대 효과 \\
\hline $\begin{array}{l}\text { 응급 } \\
\text { 환경 }\end{array}$ & 질 & $\begin{array}{l}\text { - 의료프로그램 } \\
\text { - 건축 } \\
\text { - 장비 }\end{array}$ & $\begin{array}{l}\text { - 의료계획 } \\
\text { - 건축계획 }\end{array}$ \\
\hline $\begin{array}{l}\text { 요양 } \\
\text { 환경 }\end{array}$ & 정책 & $\begin{array}{l}\text { - 공평성 } \\
\text { - 효율성 }\end{array}$ & $\begin{array}{l}\text { - 보건정책 } \\
\text { - 제도 }\end{array}$ \\
\hline $\begin{array}{l}\text { 재활 } \\
\text { 환경 }\end{array}$ & & $\begin{array}{l}\text { - 소음환경 } \\
\text { - 공기환경(감염) }\end{array}$ & - 친환경계획 \\
\hline $\begin{array}{l}\text { 정신 } \\
\text { 환경 }\end{array}$ & & $\begin{array}{l}\text { - 폐기물 } \\
\text { - 물리적 환경 }\end{array}$ & - 치유환경계획 \\
\hline $\begin{array}{l}\text { 보건 } \\
\text { 소 }\end{array}$ & 워격 & $\begin{array}{l}-\mathrm{e}-\text { Health } \\
-\mathrm{m}-\text { Health }\end{array}$ & $\begin{array}{l}\text { - 사회복지서비스 } \\
\text { - 노인/장애인 서비스 }\end{array}$ \\
\hline $\begin{array}{l}\text { 사회 } \\
\text { 복지 }\end{array}$ & 진료 & $\begin{array}{l}\text { - e-Sports } \\
\text { - u-Fitness 등 }\end{array}$ & $\begin{array}{l}\text { - 건강검진서비스 } \\
\text { - 가정간호서비스 }\end{array}$ \\
\hline
\end{tabular}

\subsection{Healthcare environment for disease prevention, treatment, and recovery}

보건의료서비스 환경은 병원, 응급, 요양, 재활, 정신, 공 중보건과 사회복지 환경으로 구분되며, 접근성, 비용, 질, 정책, 환경과 IT환경 등의 관점에서 검토되어야 한다(Table 6). 특히 의료환경의 분산화 경향과 이들 간의 네트워크 기 반에 기초한 효과적인 도시 및 지역의 보건의료 및 사회복 지 전달체계를 통해 의료서비스가 우리의 일상생활 환경과 도시환경의 구석구석까지 흘러들어갈 수 있는 환경을 구축 할 필요가 있다. $\mathrm{u}-\mathrm{Health}$ 는 이러한 환경 구축에 매우 효 과적이다. 질병이 생겼을 때 의료기관을 찾아 질병을 치료 하던 기존의 의료 개념에서 벗어나, 개인의 일상생활 환경 을 중심으로 질병을 예방하고, 건강을 관리하고 개인의 삶 의 질을 향상시킨다. 전자 칩과 센서는 언제 어디서나 몸의 건강 상태 또는 앞으로의 건강 상태에 영향을 미칠 수 있는 주변 요소 등 관련된 의료 정보들을 실시간으로 감지함은 물론, 유해 가능 요소에 적절히 대응하도록 할 수 있다.

\section{Conclusion}

본 연구는 건강의 결정요인과 환경과의 복합적인 관계에 대한 일련의 이론적 발전과정을 고찰하고 건축, 도시분야의 
건강관련 연구의 동향을 분석함으로서 건강한 건축 및 도 시환경의 구축을 위한 통합적인 연구모델을 제시하였다.

1) 모델은 건강수준(예방에서 재활까지), 사람(건강한 사람부터 장애인까지) 그리고 환경(보건의료서비스 환경, 건축환경, 도시환경)과의 관계를 개념화하였다

2) 그 적용영역으로서 첫 번째 환경은 생태적 건축도시 환경이다. 인간의 건강을 위해서는 기본적으로 정주하는 '물리적인 환경의 건강'이 필요하며, 건강한 모든 사람을 대 상으로 안전, 위생과 같은 기초예방을 위한 건강지원 환경 을 지향한다. 연구방법론은 친환경 분야의 생태학적 접근방 법이며, 치유와 근거기반디자인 연구로 검증되어야 한다.

3) 두 번째 환경은 우리가 살아가는 일상생활환경이다. 일상생활을 영위하지만, 잠재적이거나 질병 직전의 단계까 지 건강의 위험이 있는 사람들의 '건강한 생활'을 위한 건강 증진 환경의 구축을 지향한다. 연구접근방법은 생애주기에 따른 건축환경(주거/학교/직장 등)의 건강건축계획으로 치 유환경 및 근거기반디자인 방법론을 도입한다. 기존의 기능 적인 건축계획론과 차별화되는 건강중심의 기술이 필요하 다. 또한, 건축환경에 한정하지 않고 우리가 출퇴근하는 승 용차의 건강한 인테리어나 선박, 비행기 등 인간이 존재하 는 모든 공간의 건강조건을 탐구하도록 한다.

4) 세 번째 환경은 보건 및 의료복지서비스 환경이다. 인 간이 건강하기 위해서는 환경도 중요하지만, 무엇보다 사람 자체가 건강해야 한다. 이것은 생의학적 개념의 질병 예방, 치료 그리고 재활의 영역이지만, 직접적인 의료행위를 수행 하는 의료복지시설을 제외하면 일반건축과 도시공간에서 는 언제 어디서나 가능한 보건복지서비스의 접근성이 중요 하다. 본래 영역인 치유환경 및 근거기반디자인 방법론을 사용한다.

5) 이러한 환경을 복합한 건강한 건축 도시는 안전과 예 방을 위한 생태환경도시의 기반위에 건강증진이 필요한 생 애주기별 생활환경의 지주가 세워지고 그 위에 모든 건축 및 도시공간에 접근이 가능한 보건의료 서비스 환경이 얹 혀 져 연결되는 통합 이미지를 갖는다. 도시는 치유환경으 로 덮여지고, 서비스의 지원이 항상 가능한 유비쿼터스 환 경으로 감싸여진다.

향후 이 연구모델에 기초하여 생애주기에 따른 건축 및 도시공간의 건강건축계획을 정리해 나가면서 본 연구모델 은 보완되어야 하며, 종합적인 건강공간의 기준으로 발전되 어 나가야 할 것이다.

Acknowledgements: This paper was developed from following two proceedings; (1) Kwangseok Choi, 2012, A Study on the integrated Approaches for Health, Architecture and Urban Environment, Research Paper of Annual Conference of the KIHA, PP.15-
18; (2) Kwangseok Choi, 2008, Environmental Factors for Healthy City, The Architectural Society of China, PP.192-195.

\section{References}

1. Acheson, D., 1998, Independent Inquiry into Inequalities in Health. London: Stationery Office.

2. AFHC, 2006, Regional Framework for Health Promotion 20022005.

3. Alan Dilani, 2001, A New Paradigm of Design and Health.

4. Bartley M., 2004, Health inequality: an introduction to theories, concepts and methods. Cambridge: Polity.

5. Barton and Marcus Grant, 2006, A health map for the local human habitat, Journal of the Royal Society for the Promotion of Public Health, 126 (6) pp252-261.

6. Dahlgren G. and Whitehead M., 1991, Policies and strategies to promote social equity in health. Stockholm Institute for Future Studies.

7. Donna Lloyd, Sallie Newell, 2004, Health inequity: a review of the literature.

8. Gillian Pascall, 2007, Health and Health Policy, P.413.

9. GGHC, 2007, the Green Guide for Health Care, PP2-1 2-3.

10. Göran Dahlgren, Margaret Whitehead, 2006, Levelling up (part 2): a discussion paper on European strategies for tackling social inequities in health.

11. Hamilton K., 2003, The four levels of evidence based practice. Healthcare Design, 3, 18-26.

12. Health Service Executive National Health Promotion Office, 2011, Health Promotion Strategic Framework.

13. IUHPE(The International Union for Health Promotion and Education), 1999, The Evidence of Health Promotion Effectiveness; A Report for the European Commission.

14. Konarski K. 1992. Jordmån för ett gott liv, (Fertile soil for good life), Karolinska Institutet.(in Swedish) Stockholm.

15. Kwangseok Choi, 2012, A Study on the integrated Approaches for Health, Architecture and Urban Environment, Research paper of Annual Conference of the KIHA, PP.15-18.

16. Kwangseok Choi, 2008, Environmental Factors for Healthy City, The Architectural Society of China, PP.192-195.

17. Levi L., 1972, Psycho-social Factors in Preventive Medicine, In background papers to Healthy People.

18. L.J. Duhl \& A.K. Sanchez, 1999, Healthy cities and the city planning process, Health Documentation Services.

19. Michael O'donell, 1999, Health Promotion: An Emerging Strategy for Health Enhancement and Business Cost Savings in Korea. 
20. National Academy of Sciences, 2001, Preparing for an Aging World: The Case for, P204.

21. National Academy of Sciences, 2001, Preparing for an Aging World: The Case for, P204.

22. WHO, 1986, Ottawa Charter for Health Promotion.

23. Roger S. Ulrich, 1984, View Through a Window May Influence Recovery from Surgery, Science. 224, 420-421.

24. Roger S. Ulrich, 1991, Effects of interior design on wellness: Theory and recent scientific research. Journal of Health Care Interior Design, 3(1), 97-109.

25. Roger S. Ulrich, Craig Zimring, Xuemei Zhu, Jennifer DuBose,Hyun-Bo Seo, Young-Seon Choi, Xiaobo Quan, 2008, Anjali JosephA Review of the Research Literature on Evidence-Based Healthcare Design.

26. Shaw M., Galobardes B., Lawlor D.A., Lynch J., Wheeler B. and Davey Smith G., 2007, The handbook of inequality and socioeconomic position. Bristol: The Policy Press.

27. Shaw, M. et al., 2008, Chapter 11: Health and Disability, in T. Ridge and S. Wright (Eds.) Under-standing Poverty, Wealth and Inequality: Policies and Prospects, Bristol: Policy Press ,pp.235-258.

28. The Ministry of Health of New Zealand, 2002, Reducing Inequalities in Health.

29. WHO CSDH(Commission on Social Determinants of Health), 2010, A Conceptual Framework for Action on the Social Determinants of Health.

30. WHO Regional Office for Europe, 1995, City health profiles: how to report on health in your city, Copenhagen, WHO Healthy Cities Project Office.

31. 강영호, 2012, 한국사회 양극화와 건강 불평등(국립암센터 교육자 료).

32. 김동현, 2011 , 건강의 사회적 결정요인(서울대병원 공공의료강 좌-공공의료정책특론).

33. 김원철, 2011, 서초구서 태어난 남아 강북구보다 5년 더 산다, 돈 없어 치료 못받고, 중단하고 $\cdots 100$ 세 시대? 가는 길이 다르다, 국 민일보 쿠키뉴스.

34. 남정자, 1999 , 건강증진연구사업의 발전방향(특집토론; 건강증진 연구사업의 현황과 발전방향).

35. 보건복지부, 한국보건산업연구원, 2012, OECD Health Data 2012 를 통해 본 우리나라의 보건의료실태.

36. 서울시 복지건강실 보건정책과, 2012, 보도자료; 서울시, 건강격 차 해소에 본격 나선다.

37 , 이부옥, 2003, 건강도시 프로젝트란 무엇인가?

38. 최광석, 김길채, 2002 , 한국병원의 스트레스에 대응한 치유환경조 건에 관한 연구, 「한국의료복지시설학회지」제 8권 1 호.

39. 최광석, 2002 , 한국의 병원건축과 치유환경의 현황, 치료환경의
세계적 추이, 한국의료복지시설학회 국제심포지엄.

40. 최광석, 2010, 건강주택, 주택디자인(대한건축학회), 기문당, PP.134-145.

41. 최용준 외, 2007 , 건강 불평등 연구에서 사회경제적 위치 지표의 개념과 활용, 예방의학회지 제 40권 제6호 PP.475-486.

42. 한겨례, 2006, [2006연중기획 함께넘자 양극화]1부 건강불평등사 회, (1) 동네마다 수명 다르다.

접수 : 2012년 12월 31일 1차 심사 완료 : 2013년 1월 17일 게재확정일자 : 2013년 1월 17일 3인 익명 심사 필 